\title{
Producing energy while sequestering carbon? The relationship between biochar and agricultural productivity
}

\author{
Nathan Kauffman ${ }^{\mathrm{a}, 1}$, Jerome Dumortier ${ }^{\mathrm{b}, *}$, Dermot J. Hayes ${ }^{\mathrm{c}}$, Robert C. Brown ${ }^{\mathrm{d}}$, David A. Laird ${ }^{\mathrm{e}}$ \\ ${ }^{a}$ Federal Reserve Bank of Kansas City, Omaha, NE 68102 \\ ${ }^{b}$ School of Public and Environmental Affairs, Indiana University-Purdue University Indianapolis, Indianapolis, IN \\ 46202 \\ ${ }^{c}$ Department of Economics, Iowa State University, Ames, IA 50011 \\ ${ }^{d}$ Department of Mechanical Engineering, Iowa State University, Ames, IA 50011 \\ ${ }^{e}$ Department of Agronomy, Iowa State University, Ames, IA 50011
}

\begin{abstract}
A partial solution to problems associated with anthropogenic greenhouse gas (GHG) emissions could be the development and deployment of carbon-negative technologies, i.e., producing energy while reducing atmospheric carbon dioxide levels. Biofuels have been considered a possibility but have faced limitations due to competition with food production and GHG emissions through indirect land-use change (ILUC). In this article, we show how emissions from ILUC can potentially be reduced by producing food and bioenergy from biochar amended soils. The possibility of yield improvements from biochar would reduce the land requirement for crop production and thus, lead to a reduction in emissions from ILUC. In our application, biochar and bio-oil are produced via fast pyrolysis of corn stover. Bio-oil is subsequently upgraded into a fuel suitable for use in internal combustion engines. Applying the U.S. regulatory method used to determine biofuel life cycle emissions, our results show that a biochar-induced yield improvement in the U.S. Midwest ranging from $1 \%$ to $8 \%$ above trend can lead to an ILUC credit between 1.65 and $14.79 \mathrm{t} \mathrm{CO}_{2}$ equivalent ha $^{-1}$ year $^{-1}$ when future emissions are assessed over the next 30 years. The model is generalizable to other feedstocks and locations and illustrates the relationship between biochar and crop production.
\end{abstract}

Keywords: Biochar, life cyle analysis, biofuel, yield improvement

\section{Introduction}

Producing food and energy while sequestering carbon is a difficult goal to achieve. Biofuels produce energy but directly compete with food production and have carbon-positive life cycles.

\footnotetext{
*Corresponding author

Email address: jdumorti@iupui .edu (Jerome Dumortier)

${ }^{1}$ The views expressed are those of the authors and do not necessarily reflect the positions of the Federal Reserve Bank of Kansas City or the Federal Reserve System.
}

This is the author's manuscript of the article published in final edited form as:

Kauffman, N., Dumortier, J., Hayes, D. J., Brown, R. C., \& Laird, D. A. (2014). Producing energy while sequestering carbon? The relationship between biochar and agricultural productivity. Biomass and Bioenergy, 63, 167-176. http://dx.doi.org/10.1016/j.biombioe.2014.01.049 
Bioenergy could achieve carbon-neutrality from a life cycle perspective if the amount of $\mathrm{CO}_{2}$ removed from the atmosphere, directly and indirectly, is equal to the amount emitted into the atmosphere over the entire fuel cycle. Conventional biofuels, such as corn grain ethanol, are considered carbon-positive since more greenhouse gases (GHG) are emitted especially through indirect landuse change (ILUC). ILUC is a component of GHG emissions calculations that is required by law in biofuel life cycle analysis (LCA). Regulatory policy therefore adopts a consequential life cycle methodology ${ }^{2}$. The economic and life cycle logic behind ILUC for biofuel production used by the U.S. Environmental Protection Agency (EPA) is as follows: Increased demand for biofuel feedstock causes crop prices to rise. This price increase provides farmers a greater incentive to utilize land, possibly forest, to replace crops being used for energy production. This land conversion generates significant emissions, particularly in the case of deforestation, which results in soil and biomass carbon to be released into the atmosphere. Although controversial since it is difficult to estimate, ILUC effects result in positive GHG emissions for some biofuels such as corn ethanol (Searchinger et al., 2008; Fargione et al., 2008; Melillo et al., 2009; Keeney and Hertel, 2009; Dumortier et al., 2011).

Theoretically, carbon-negative biofuels are attainable if the pathway releases a smaller amount of GHG emissions than what it extracts from the atmosphere, most likely by employing carbon sequestration. Including ILUC effects in life cycle calculations can result in negative emissions through avoided deforestation or afforestation. This could occur if the pathway used to produce biofuels generates sufficient crop yield increases such that less land is needed for agriculture and if the permanent increase in crop yields is attributed to the biofuel pathway. The objective of this study is to explore whether carbon-negative biofuels are attainable from a fast pyrolysis system when biochar is used as an agricultural soil amendment, resulting in an increase in crop yields, and when offsetting effects associated with ILUC are used as part of a consequential LCA. This LCA uses EPA's methodology for measuring indirect land-use change, but in this case the impact of the ILUC calculation is to improve the carbon balance of the system by reducing the need for new land hectares by improving yields on existing hectares.

It is important to note that for our results to hold, it does not matter whether grain is used to produce food or fuel. We just require an "interior solution" where both food and biofuels (ethanol in our case) must be produced somewhere and that neither ever goes to zero. The ILUC credit is independent of ethanol production if we make the assumption that the yield increases can displace acreage used to produce ethanol elsewhere and that the biochar does not necessarily have to go back to the same hectare it was extracted from (which might be used for food production).

\section{Biochar Characteristics}

There has been increasing recognition that biochar could play a significant role in the realization of carbon-negative bioenergy production when used as a soil amendment (Lehman, 2007;

\footnotetext{
${ }^{2}$ Throughout the paper, we are considering consequential life cycle analysis (LCA) as opposed to attributional LCA. Attributional life cycle analysis includes direct effects such as carbon sequestered by the biofuel feedstock. Consequential life cycle analysis includes also indirect effects such as cropland reallocation and the resulting indirect land-use change emissions.
} 
Renner, 2007; Mathews, 2008). Using biochar for this purpose dates back to the pre-Columbian Amazon where natives are believed to have applied it to agricultural soils, resulting in what is known locally as terra preta, or black earth soils (Blackwell et al., 2009). Hundreds of years later, these soils have been found to be significantly more fertile than comparable surrounding regions (Marris, 2006). Within the context of our biofuel pathway, there are four general merits of biochar application to agricultural soils: its role in carbon sequestration, potential reduction in nitrous oxide $\left(\mathrm{N}_{2} \mathrm{O}\right)$ emissions, its impact on soil organic carbon levels, and its effect on crop yields.

Biochar is composed of a large amount of highly stable carbon and sequesters carbon if used as an agricultural soil amendment (Brewer et al., 2009). Biochar quality, as measured by the amount of labile versus recalcitrant carbon, influences its carbon sequestration potential (Bruun et al., 2011). Labile carbon will be mineralized by soil microorganisms in a relatively short period of time whereas recalcitrant carbon will be stable for hundreds or possibly thousands of years (Lehmann et al., 2009). Furthermore, biochar containing labile carbon can stimulate soil organic matter mineralization through a priming effect. However, in the long-term biochar enhances stabilization of biogenic organic compounds through adsorption and humification (Zimmerman et al., 2011; Rogovska et al., 2011).

Reduced need for synthetic nitrogen fertilizer in crop production is anticipated because biochar decreases losses of nitrogen due to nitrate leaching and because biochar may reduce $\mathrm{N}_{2} \mathrm{O}$ emissions. Biochar applications decrease soil bulk density and thereby increase porosity and enhance soil aeration (Laird et al., 2010). Hence reduced denitrification is one potential explanation for reported reductions in $\mathrm{N}_{2} \mathrm{O}$ emissions from biochar-treated soils (Rogovska et al., 2011; Yanai et al., 2007). Another potential mechanism for decreased $\mathrm{N}_{2} \mathrm{O}$ emissions in biochar-amended soils may be an increased adsorption of ammonium cations $\left(\mathrm{NH}_{4}^{+}\right)$and/or $\mathrm{N}$-containing organic compounds, which reduce both $\mathrm{N}$ leaching and $\mathrm{N}_{2} \mathrm{O}$ emissions (Singh et al., 2010). While most studies have shown reductions in $\mathrm{N}_{2} \mathrm{O}$ emissions for soils amended with biochar relative to control soils (Angst et al., 2013; Cayuela et al., 2013), no significant differences and even small increases between biochar-amended soil and controls in $\mathrm{N}_{2} \mathrm{O}$ emissions have been reported (Karhu et al., 2011; Scheer et al., 2011).

Biochar amendments have the potential to enhance the retention of plant nutrients and water by soils. This results in a decrease in nutrient leaching (Singh et al., 2010; Liang et al., 2006; Laird et al., 2010; Novak et al., 2010) and an increase in plant available water retention (Laird et al., 2010; Karhu et al., 2011). Both are anticipated to increase net primary production and/or improve nutrient and water use efficiency in crop production. Any increase in net primary production due to biochar will increase the input of plant residue carbon to soils, which will help build biogenic soil organic matter. While increasing soil carbon sequestration, this would also lessen the need to leave corn stover unharvested to maintain soil organic matter, allowing a larger share to be sustainably removed (Mullen et al., 2010; Wilhelm et al., 2007).

Several studies show a positive effect on crop yields, particularly when applied to degraded soils in the tropics (Glaser et al., 2002; Kimetu et al., 2008; Major et al., 2010). In the case of biochar applied to corn in Colombia, yield increases as high as 140\% were observed, with a $28 \%$ increase in the second year of the study (Major et al., 2010). The Columbian corn study was conducted on degraded soil in the tropics using slow pyrosis biochar from wood which is different from the analysis in the present paper. The yield increase above trend on already highly productive 


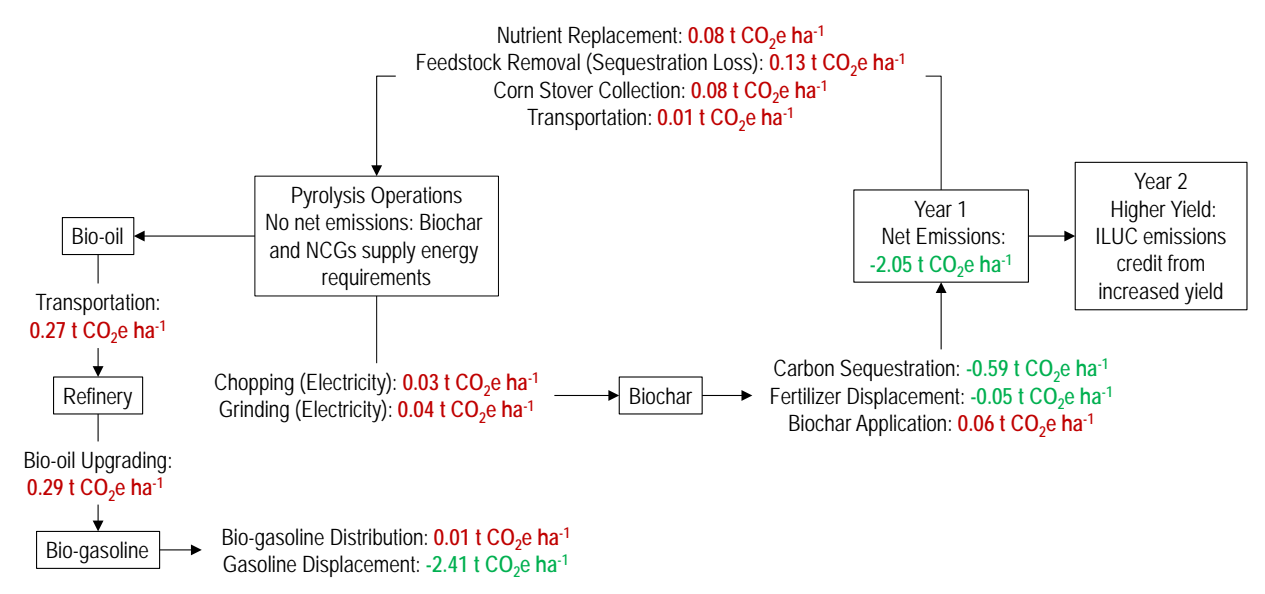

Figure 1: Static stages and emissions associated with fast pyrolysis of corn stover. The process begins with 1 hectare of corn in the box labeled "Year 1" and continues counter-clockwise. At the end of the process, biochar is applied to cropland soil which generates a potential increase in crop yields.

soils in the U.S. Midwest might be difficult to achieve. Thus, we calculate the break-even yield improvement necessary over the life cycle of 30 years. In addition, the effects of biochar on yield are highly variable and not all studies have shown a positive impact of biochar on crop yields (Spokas et al., 2010). However, interactions between biochar quality, soil quality, climate, and cropping systems are still in early stages of investigation, highlighting a need for further research on the interactions between biochar and agricultural soil (Gaskin et al., 2010).

Our approach highlights the yield improvement necessary and we conduct a sensitivity analysis as well. The method is not limited to a particular feedstock or location and shows that the potential yield improvement can alter LCA significantly.

\section{Scope of Study}

The function of the product system is to produce ethanol and bio-oil from corn and corn stover for use in transportation vehicles with a system that results in carbon-neutrality. The functional unit is $1 \mathrm{MJ}$ of energy. The system boundaries are spatially defined to include both corn grain and corn stover from one hectare of land harvested over a 30 year period. As can been seen in Figure 1, the system begins with fertilizer and equipment used to produce the corn and ends with the delivery of the fuel to a gasoline station. Total pathway emissions are attributed to ethanol and determined based on the use of the entire hectare. Any saved emissions from marginal biogasoline or biochar production are subtracted from this total, where marginal bio-gasoline is taken to displace gasoline and diesel (half of each).

\section{Life Cycle Analysis}

The agricultural and forestry sector can produce biochar from crop residues (corn stover, wheat straw, sugar cane), forestry residues, and animal manures. As mentioned before, biochar has the 
potential to increase yields if applied to cropland. If biochar is amended to the soil and enhances crop yields permanently above the trend, less land will be needed for crop production in the future or, put differently, more production is possible on the same area of land. We model the production of biochar and bio-gasoline using fast pyrolysis and apply the resulting biochar to cropland (Laird et al., 2009). We chose fast pyrolysis to produce biochar because it also yields a valuable by-product, bio-oil, which can be upgraded into a drop-in fuel. Fast pyrolysis produces 10-20 wt $\%$ which seems a modest yield compared to the $40 \mathrm{wt} \%$ resulting from slow pyrolysis. The drawback of slow pyrolysis is that it produces "producer gas" as a co-product which is of relatively low economic value. The amount of biochar produced from fast pyrolysis during the production of transportation fuels would be large. Brown et al. (2011) demonstrate that fast pyrolysis has superior economics for the production of biochar compared to slow pyrolysis because of the higher value of the energy co-products. As detailed in Brown et al. (2011), all process energy requirements for pyrolysis have been accounted for.

Following the biochar application, we assume a range of yield improvements ranging from $0 \%$ to $8 \%$ in addition to calculating the break-even yield improvement necessary to achieve carbon neutrality. Given yield improvements after biochar application, we can determine the ILUC credit for avoiding expansion of cropland. The harvested corn can either be used for food production or corn ethanol production. The fundamental stages and static baseline emissions of fast pyrolysis of corn stover are illustrated in Figure 1. Aspects surrounding bio-oil as an alternative energy source for electricity generation have been studied fairly extensively (Grassi and Bridgwater, 1993; Bridgwater et al., 2002). In recent years, interest in the potential for bio-oil to be upgraded via hydro-processing to bio-gasoline has grown (Wright et al., 2010; Hsu, 2011). The key feature that makes this an attractive process is the ability to use bio-gasoline as a drop-in fuel in existing internal combustion engines, displacing conventional crude-based transportation fuels and generating a further reduction in GHG emissions.

Our pathway assumes that ethanol is produced from corn grain. A fraction of the remaining corn stover is harvested and subjected to fast pyrolysis to produce biochar and bio-oil. The bio-oil is then upgraded to bio-gasoline (naphtha and diesel range stock fuel) and the biochar is returned to cropland soil as an agricultural amendment. Emission factors for the segment of production associated with corn stover are taken from the Greenhouse Gases, Regulated Emissions, and Energy Use in Transportation (GREET) model. Our life cycle emissions calculations include processes from field to wheels in producing ethanol. Following the literature on LCAs for cropping systems and interdependent crop rotations, we adopt a system expansion approach with the functional unit defined as $1 \mathrm{MJ}$ of energy to facilitate comparisons between ethanol (E10 fuel) and gasoline (Kim and Dale, 2005; Kim et al., 2009; Luo et al., 2009). System boundaries are spatially defined to include both corn grain and corn stover from one hectare of land. Total pathway emissions are attributed to ethanol and determined based on the use of the entire hectare. Any saved emissions from marginal bio-gasoline or biochar production are subtracted from this total, where marginal bio-gasoline is taken to displace gasoline and diesel (half of each). Life cycle emissions associated with corn grain ethanol are taken from the EPA 2012 analysis $^{3}$. Life cycle processes and emission calculations for fast pyrolysis of corn stover are presented in what follows for the first year of the

\footnotetext{
${ }^{3}$ U.S. Congress, Energy Independence and Security Act of 2007 (Public Law No: 110-140, Washington D.C.,2007)
} 
biofuel pathway. This implies that the corn stover removal rate is $40 \%$ and any yield improvements from biochar application have not yet taken effect. These effects would begin in the second year.

\subsection{Corn Stover Harvesting and Transportation}

Once harvested, the corn stover is transported to a pyrolysis facility assumed to process 70,000 tons per year in an area where $20 \%$ of the land is allocated to corn, i.e., a crop density of 0.2 . This results in an average hauling distance of 13.4 kilometers, where the hauling distance is a function of corn stover yield, crop density, and plant size (French, 1960). We also allow for a loss in carbon sequestration due to feedstock removal where it is assumed that $45 \%$ of corn stover is comprised of carbon, of which $2 \%$ is taken from the soil (McCarl et al., 2009).

\subsection{Corn Grain Ethanol Life Cycle Emissions}

Emissions from corn grain ethanol are held fixed on a "per MJ" basis with the exception of emissions from land-use change, which are fixed on a "per ha" basis. These emissions are based on the EPA 2012 life cycle calculations to represent a near-term scenario. A summary of the EPA 2012 life cycle emissions calculations is provided in the table 1 under the assumption that yields are $11.6 \mathrm{tha}^{-1}$.

\subsection{Pyrolysis and Upgrading Operations}

It is assumed that additional nutrients must be provided to compensate for the loss due to corn stover removal, generating further emissions. Once the corn stover has been transported to the pyrolysis facility, it is pre-treated, through chopping and grinding, to a final size of $3 \mathrm{~mm}$. Electrical energy needed for chopping is $31.9 \mathrm{MJ} \mathrm{t}^{-1}$ (Mani et al., 2004) and for grinding is $39.6 \mathrm{MJ}$ $\mathrm{t}^{-1}$ (Bitra et al., 2009). We assume that the pyrolysis process is fully integrated and that one-third of biochar produced, in addition to all non-condensable gases (NCGs), are sufficient to provide all of the internal process heat (Wright et al., 2010). Bio-oil, biochar, and NCG yields are taken to be $61.7 \%, 17.0 \%$, and 21.9\%, respectively (Mullen et al., 2010). Collected biochar is transported back to the field and applied to the soil as an amendment. It is assumed that the trucks delivering corn stover also haul biochar back to the field so that emissions for this segment have already been accounted for in the transportation of stover. Bio-oil is subsequently transported to existing refineries to be upgraded into bio-gasoline with the average one-way hauling distance assumed to be 400 $\mathrm{km}$ (approximately the west-to-east distance of the state of Iowa). The last phase of bio-gasoline production is hydroprocessing and refining where we assume that refining is possible with negligible modifications in infrastructure (Huber and Corma, 2007). Pyrolysis is gaining traction among many integrated energy companies because it comes closest to resembling standard refining operations among the many options for producing sustainable transportation fuels from lignocellulose. This does not mean that significant infrastructure changes are unnecessary if lignocellulose is to be converted into gasoline and diesel. Our paper is based on the process modeling of pyrolysis-based fuels of Wright et al. (2010), which accounts for all infrastructure needed to produce bio-oil and upgrade it to finished fuels. Thus, the extent of build out is not limited by current infrastructure but

and U.S. Environmental Protection Agency, Regulation of Fuels and Fuel Additives: Changes to Renewable Fuel Standard Program; Final Rule (Federal Register, 40 CFR Part 80, Washington D.C., 2010) 
upon societal acceptance of biofuels as a means to reduce GHG emissions. The carbon balance is not dependent on the level of adoption. For hydroprocessing, it is assumed that $38 \%$ of bio-oil produced is used to generate the necessary hydrogen Wright et al. (2010). As detailed in Wright et al. (2010), deoxygenation of heavy fraction of bio-oil is accomplished with hydrogen obtained through steam reforming of the aqueous phase of the bio-oil.

\subsection{Biochar Application, Fertilizer Displacement, and Carbon Sequestration}

Once returned to the field, biochar is applied at a rate of $24.7 \mathrm{t} \mathrm{ha}^{-1}\left(10 \mathrm{t} \mathrm{acre}^{-1}\right)$ and generates an emissions credit by sequestering carbon. The fixed carbon content of fast pyrolysis biochar made from herbaceous biomass is approximately $37.8 \%$ (Brewer et al., 2009). There is also likely to be a synergistic relationship between biochar and cropland soil that would result in decreased synthetic fertilizer needs. As discussed earlier, it is possible that this decrease may be substantial. For the baseline as well as the above-trend yield improvement, we have included fertilizer application and the resulting emissions from the EPA GHG emissions for corn grain ethanol. For the scenario, we correct this emission factor by allowing a decrease in the fertilizer application rate by reducing fertilizer application by $0.394 \mathrm{~kg} \mathrm{~N}_{2} \mathrm{O} \mathrm{t}^{-1}$ of biochar applied (Roberts et al., 2010). This generates an emissions credit of $0.013 \mathrm{t} \mathrm{CO}_{2} \mathrm{e} \mathrm{t}^{-1}$ of corn stover removed $\left(0.05 \mathrm{t} \mathrm{CO}_{2} \mathrm{e} \mathrm{ha}{ }^{-1}\right)$. As presented here, this pathway results in net GHG emissions of $-2.05 \mathrm{t} \mathrm{CO}_{2} \mathrm{e} \mathrm{ha}^{-1}$ as shown in figure 1. In our sensitivity analysis, we also include the reduction of $\mathrm{N}_{2} \mathrm{O}$ emissions after biochar application.

\subsection{Indirect Land-Use Change Emissions Credit}

For land that has been treated with biochar, we allow for the possibility that this treatment provides an increase in yield trends. Corn yield projections are calculated by fitting a linear trendline to the 2011 FAPRI Outlook (15 year) projections and extending this projection to 30 years ${ }^{4}$. An increase in yields allows a greater amount of ethanol, bio-gasoline, and biochar to be produced from a given plot of land. Intensification of ethanol production allows land elsewhere, which would have been converted to cropland to produce this additional amount of ethanol, to return to its native state. This avoided land-use change brought about by yield improvements results in an emissions credit associated with the marginal increase in ethanol production. The credit obtained is taken to be equal to the 30-year average annualized international ILUC emissions as determined by the EPA, i.e., $76 \mathrm{~g} \mathrm{CO}_{2} \mathrm{e} \mathrm{MJ}^{-1}$. An essential element of our modeling approach is to show that crop yield increases could only have occurred if the particular biofuel production system were in operation.

\subsection{Life Cycle Emissions Per Hectare}

There are three life cycle components that determine the magnitude of emissions in a given year. The first is life cycle emissions attributed to corn grain ethanol. The second component is life cycle emissions attributed to biochar and bio-gasoline produced via fast pyrolysis of corn stover. Emissions for this portion of the pathway are calculated based on yields and other parameters as

\footnotetext{
${ }^{4}$ Food and Agricultural Policy Research Institute (FAPRI), World Agricultural Outlook Database. (2011). http://www.fapri.iastate.edu/tools/outlook.aspx
} 

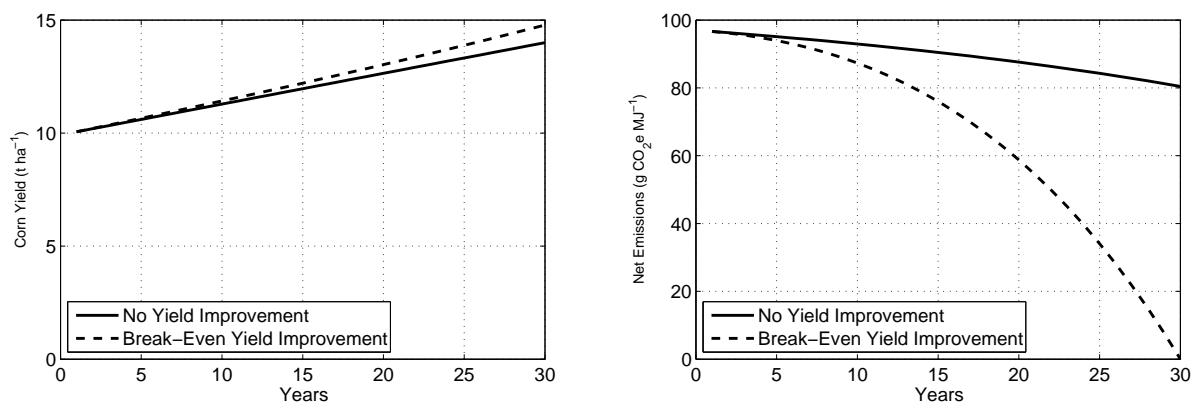

Figure 2: Yield and accumulated net GHG emissions assessed over 30 years without biochar-induced yield improvement and with break-even biochar-induced yield improvement of 5.89\%.

reported in table 2 and the supplementary Information for each year in the time horizon. The final component is the credit obtained from a biochar-induced increase in yield on ethanol production above the baseline. It is important to recognize that it is the cumulative net emissions of all future years combined that determines the percentage of emissions reduction in the first year. The pathway is not carbon-negative in the first year alone, or any other year individually. The consideration of emissions over a 30 year time horizon is consistent with the EPA regulatory approach.

\section{Results}

Our baseline is called "No Yield Improvement" and we assume no yield-improving effects of biochar. In the baseline, yield grows at the projected increase from the previously mentioned 2011 FAPRI Outlook. Net pathway emissions are $80.4 \mathrm{~g} \mathrm{CO}_{2} \mathrm{e} \mathrm{MJ}^{-1}$ which is $15.9 \%$ lower than the 96 $\mathrm{g} \mathrm{CO}_{2} \mathrm{e} \mathrm{MJ}^{-1}$ for gasoline (Searchinger et al., 2008). Figure 2 depicts the yield under the baseline which corresponds to the trend yield and the net pathway emissions assessed over 30 years. The scenario is called "Break-Even Yield Improvement" in which we calculate the yield improvement from biochar necessary to achieve zero net pathway emissions over the 30 year period. This yield amounts to an above-trend yield improvement of 5.89\%. Given our assumptions and the yield improvement of $5.89 \%, 93 \%$ of a specific plot of land will have received biochar treatment at the end of the 30 year time period. Thus, yields are 5.5\% higher (panel (a) in Figure 2) than the baseline case by the end of 30 years $(0.93 \times 0.0589)$. If biochar applied to cropland increases yields by $5.89 \%$ above trend, then we have a carbon neutral system, i.e., the net pathway emissions are zero. As shown in figure 3b, for yield improvements above $5.89 \%$, net pathway emissions are negative. The net pathway emissions in figures $3 \mathrm{~b}, 4,5$ are cumulative figures assessed over 30 years. Therefore the carbon-neutrality of the system depends on the assumption that we can obtain credit today for yield improvements that will last for thirty years. This accounting procedure uses the exact procedure used by the EPA to calculate ILUC. We then evaluate the effects based on the contribution of the system to the stock of $\mathrm{CO}_{2}$ in the atmosphere. As an example, consider the case for 2025. The baseline yield projection (as determined from FAPRI) is $11.82 \mathrm{t} \mathrm{ha}^{-1}$. With biochar applied to portions of a given field each year, this yield is increased to $12.05 \mathrm{t} \mathrm{ha}^{-1}$. The 

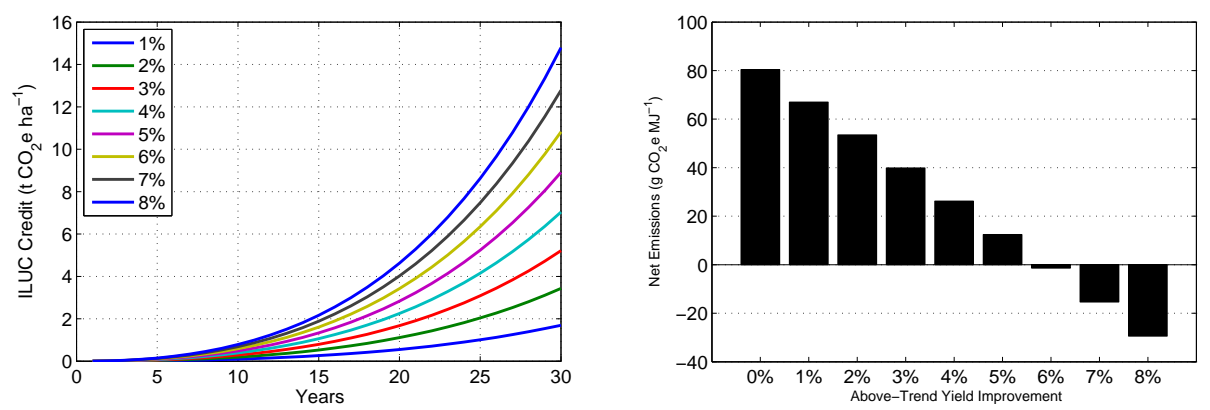

Figure 3: Indirect land-use change (ILUC) credit and net GHG emissions assessed over 30 years for biochar-induced yield improvements ranging from $0 \%$ to $8 \%$.

increased yield improves net biochar and bio-oil production, which is taken into account when determining life cycle emissions. Based on this $0.23 \mathrm{t} \mathrm{ha}^{-1}$ yield increase, an additional $38.9 \mathrm{~L}$ of ethanol (824 MJ of bioenergy) is produced and attributed to biochar application. With international ILUC emissions taken as $76 \mathrm{~g} \mathrm{CO}_{2} \mathrm{e} \mathrm{MJ}^{-1}$, this marginal increase in ethanol production generates an emissions credit of $0.025 \mathrm{t} \mathrm{CO}_{2} \mathrm{e}$. Similar calculations are done for each year in the 30 year time horizon under consideration. The ILUC credit is cumulative over the years because the yield increase is permanent. A summary of the dynamic calculation of each of these components for each of the 30 years in the time horizon is presented in tables 3 and 4 . Total emissions per hectare are also presented in those tables. The total per hectare is converted to a measure of $\mathrm{g} \mathrm{CO}_{2} \mathrm{e}$ $\mathrm{MJ}^{-1}$ based on the energy yield of ethanol per hectare. Table 1 in the manuscript illustrates the importance of international land-use change emissions which account for $63.79 \%$ of total corn grain ethanol emissions. The carbon stock in a hectare of native vegetation can be significant especially in the case of forest. So even if a relatively small area of forest is "saved", the GHG balance is affected significantly. This has been illustrated by Hertel et al. (2010) and Dumortier et al. (2011). How important those savings can be illustrated with a different example involving stocking rates, i.e., animal units per hectare. If the stocking rate of cattle was improved by only $2 \%$ in Brazil, enough pasture would made available to accommodate all of the biofuel production of the United States (Gorter and Just, 2010). So the yield improvement of 5.89\% might seem small but the effects are significant. The EPA methodology assumes that the yield improvement lasts at least thirty years and it accounts for this carbon savings at the time the char is applied.

\subsection{Sensitivity Analysis}

Since we are considering a process that is not currently in commercial operation, we conduct a sensitivity analysis on variables that are either most crucial or have a high degree of uncertainty associated with them. The two most important parameters are the degree of biochar-induced yield growth and the corn stover removal rate. The ILUC credit after 30 years ranges form 1.65 and $14.79 \mathrm{t} \mathrm{CO}_{2}$-e ha ${ }^{-1}$ year $^{-1}$ for yield increases from $1 \%$ to $8 \%$ above trend (Panel (a), Figure 3). Panel (b) in Figure 3 summarizes net emissions under various biochar-induced above-trend yield improvements. Yield assumptions are important in terms of ILUC because a hectare of native vegetation can contain a large amount of carbon and small changes in yield can have a significant 


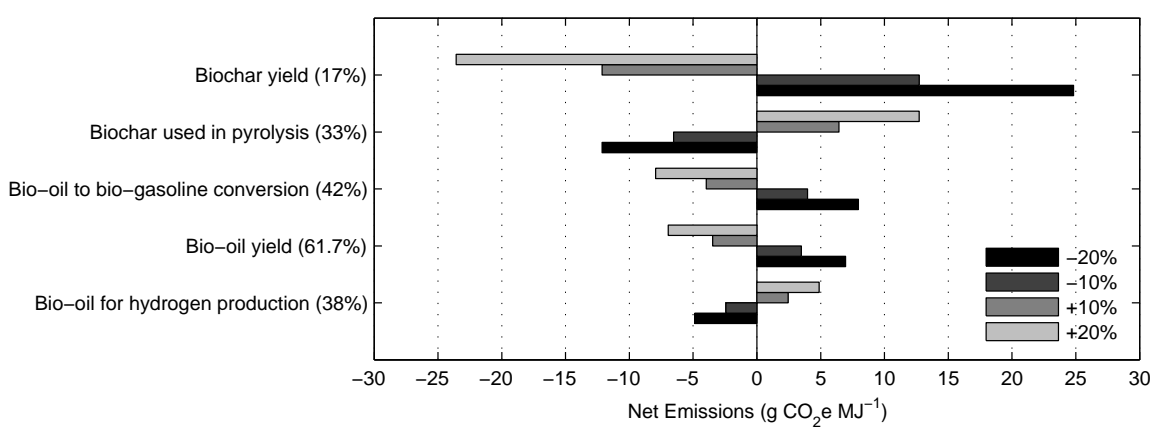

Figure 4: Net GHG emissions under the break-even yield improvement assessed over 30 years for different removal fractions with and without biochar application.

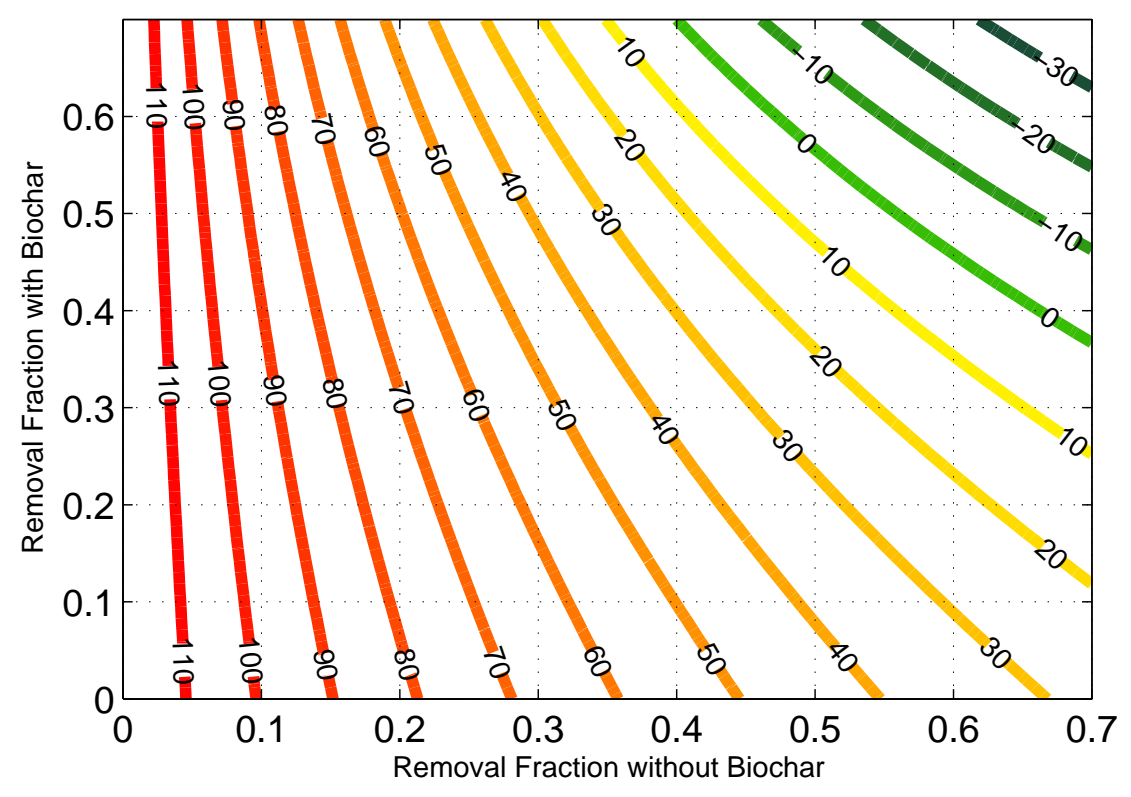

Figure 5: Net GHG emissions under the break-even yield improvement assessed over 30 years by varying key parameters $+/-10 \%$ and $20 \%$ from their base values (in parenthesis) 
effect (Hertel et al., 2010; Dumortier et al., 2011). Even a 1\% yield improvement above trend reduces emissions by $17 \%$.

The amount of corn stover that can be sustainably removed from a given plot of land has been somewhat controversial. Some studies have allowed as much as $70 \%$ to be removed whereas others have suggested as little as $25 \%$ in some areas (Sheehan et al., 2003; Kim et al., 2009). The updated U.S. Billion Ton study finds that $45 \%$ to $50 \%$ (national average) can be sustainably removed under no-till practices (Perlack and Stokes, 2011). Removal of 45-50\% of surface residue in a no-till system reduces annual inputs of labile carbon to the soil and therefore GHG emissions from the soil. Labile crop residue has a half-life in soils of approximately 6 months. By contrast, biochar carbon is highly recalcitrant and has a half-life of several hundred to over 1000 years. This difference in the intrinsic stability between biochar carbon and residue carbon is responsible for the net carbon credit. Reduced emissions of $\mathrm{N}_{2} \mathrm{O}$ are considered separately as noted above.

In our study, we allow for two different removal rates: one on land which has not been amended with biochar and a somewhat higher rate on land which has received the amendment as motivated earlier. There is still some uncertainty surrounding this rate and we also recognize that it is an important assumption affecting all subsequent results. We report baseline emissions under the assumption of $40 \%$ corn stover removal on land that has not been amended with biochar and $70 \%$ on land that has received the amendment. Variations on this assumption are provided in the sensitivity analysis (Figure 4). The results for other key parameters can be found in figure 5 where we vary the parameters by $+/-10 \%$ and $+/-20 \%$. Note that the variations of those parameters and the resulting effect on the GHG balance are linear. The effects of varying the hauling distance on GHG emissions is negligible.

As aforementioned, uncertainty about the reduction of nitrous oxide emissions remains. We have conducted a sensitivity analysis with respect to emissions from reduced fertilizer application and domestic farm inputs and fertilizer $\mathrm{N}_{2} \mathrm{O}$. In our scenario, the fertilizer need is reduced by $0.394 \mathrm{~kg} \mathrm{~N}_{2} \mathrm{O} \mathrm{t}^{-1}$ of biochar applied. Varying this value from 0 to $0.788 \mathrm{~kg} \mathrm{~N}_{2} \mathrm{O} \mathrm{t}^{-1}$ changes the yield improvement required for carbon neutrality to $5.96 \%$ and $5.83 \%$, respectively. Reducing the emissions from domestic farm inputs and fertilizer $\mathrm{N}_{2} \mathrm{O}$ to 0 requires a yield improvement of $5.51 \%$. This suggests that our results are robust to changes with respect to nitrous oxide emissions. This is consistent with domestic farm inputs and fertilizer $\mathrm{N}_{2} \mathrm{O}$ being relatively small compared to the international land-use change emissions of $76.1 \mathrm{~g} \mathrm{MJ}^{-1}$.

"Land Sparing" has been analyzed previously and found two have opposing effects. Ewers et al. (2009) argue that if yields increase, less land is needed for a given level of production which is the argument made in this paper. This is contrasted by Rudel et al. (2009) who claim that higher yields also increase the land profitability and farmers have the incentive to put the land in production to increase revenue. The elasticity of demand for agricultural products determines the magnitude of the second effect.

\section{Discussion}

Economically viable carbon-negative technologies have proven to be an elusive goal for alternative energy researchers, particularly for biofuel production. By itself, corn grain ethanol generates a non-trivial but only modest reduction in emissions as determined by the EPA in a long-term 
(2022) scenario and an increase in emissions in a near-term (2012) scenario relative to gasoline. Cellulosic technologies to produce ethanol from corn stover have been unable to overcome issues of commercial scaling. Combining the two feedstocks into a single pathway to produce ethanol from corn grain and bio-oil/biochar from corn stover via fast pyrolysis is a pathway that has the potential to be carbon-neutral or even negative given sufficient yield improvement. This is predominantly a result of the yield benefit realized by applying biochar to cropland soil.

We recognize that this system is only one of many possible carbon-negative pathways. The key to the carbon-negative result in this article is that biochar-induced yield improvements lead to an offset of emissions associated with ILUC by intensifying ethanol production. By evaluating performance over 30 years, the effects of these yield improvements are cumulative because the yield improvements are permanent.

By sequestering carbon and mitigating or reversing the effects of ILUC, this platform provides an opportunity to produce energy (ethanol and bio-gasoline) while simultaneously reducing atmospheric $\mathrm{CO}_{2}$ levels. It is a platform that could alter the perception of biofuels as a component of climate change policy.

\section{Acknowledgments}

This research was supported by partial funding from the Bioeconomy Institute (BEI) at Iowa State University. Partial funding was also provided by a Biobased Industry Center (BIC) grant. The authors declare no competing financial interests.

\section{Figure Captions}

\section{Bibliography}

Angst, T., Patterson, C., Reay, D., Anderson, P., Peshkur, T., Sohi, S., 2013. Biochar diminishes nitrous oxide and nitrate leaching from diverse nutrient sources. Journal of Environmental Quality 42 (3), 672-682.

Bitra, V. S., Womac, A. R., Igathinathane, C., Miu, P. I., Yang, Y. T., Smith, D. R., Chevanan, N., Sokhansanj, S., 2009. Direct measures of mechanical energy for knife mill size reduction of switchgrass, wheat straw, and corn stover. Bioresource Technology 100, 6578-6585.

Blackwell, P., Riethmuller, G., Collins, M., 2009. Biochar for Environmental Management: Science and Technology. Routledge, Ch. Biochar application to soil, pp. 207-222.

Brewer, C. E., Schmidt-Rohr, K., Satrio, J. A., Brown, R. C., 2009. Characterization of biochar from fast pyrolysis and gasification systems. Environmental Progress and Sustainable Energy 28, 386-396.

Bridgwater, A. V., Toft, A. J., Brammer, J. G., 2002. A techno-economic comparison of power production by biomass fast pyrolysis with gasification and combustion. Renewable and Sustainable Energy Reviews 6, 181-246.

Brown, T. R., Wright, M. M., Brown, R. C., 2011. Estimating profitability of two biochar production scenarios: slow pyrolysis vs. fast pyrolysis. Biofuels, Bioproducts and Biorefining 5, 54-68.

Bruun, E. W., Müller-Stöver, D., Ambus, P., Hauggaard-Nielsen, H., 2011. Application of biochar to soil and $n_{2} \mathrm{O}$ emissions: potential effects of blending fast-pyrolysis biochar with anaerobically digested slurry. European Journal of Soil Science 62 (4), 581-589.

Cayuela, M. L., Sánchez-Monedero, M. A., Roig, A., Hanley, K., Enders, A., Lehmann, J., 2013. Biochar and denitrification in soils: when, how much and why does biochar reduce $\mathrm{N}_{2} \mathrm{O}$ emissions? Scientific Reports 3 (1732), doi:10.1038/srep01732. 
Dumortier, J., Hayes, D. J., Carriquiry, M., Dong, F., Du, X., Elobeid, A., Fabiosa, J. F., Tokgoz, S., 2011. Sensitivity of carbon emission estimates from indirect land-use change. Applied Economic Perspectives and Policy 33 (3), 428-448.

Ewers, R. M., Scharlemann, J. P. W., Balmford, A., Green, R. E., 2009. Do increases in agricultural yield spare land for nature? Global Change Biology 15, 17161726.

Fargione, J., Hill, J., Tilman, D., Polasky, S., Hawthorne, P., 2008. Land clearing and the biofuel carbon debt. Science $319,1235$.

French, B. C., 1960. Some considerations in estimating assembly cost functions for agricultural processing operations. Journal of Farm Economics 42, 767-778.

Gaskin, J. W., Speir, R. A., Harris, K., Das, K. C., Lee, R. D., Morris, L. A., Fisher, D. S., 2010. Effect of peanut hull and pine chip biochar on soil nutrients, corn nutrient status, and yield. Agronomy Journal 102, 623-633.

Glaser, B., Lehmann, J., Zech, W., 2002. Ameliorating physical and chemical properties of highly weathered soils in the tropics with charcoal: a review. Biology and Fertility of Soils 35, 219-230.

Gorter, H. D., Just, D., 2010. The social cost and benefits of biofuels: The intersection of environmental, energy, and agricultural policy. Applied Economic Perspectives and Policy 32 (1), 4-32.

Grassi, G., Bridgwater, A. V., 1993. The opportunities for electricity production from biomass by advanced thermal conversion technologies. Biomass and Bioenergy 4, 339-345.

Hertel, T. W., Golub, A. A., Jones, A. D., O’Hare, M., Plevin, R. J., Kammen, D. M., 2010. Effects of u.s. maize ethanol on global land use and greenhouse gas emissions: Estimating market-mediated responses. BioScience 60, 223-231.

Hsu, D. D., March 2011. Life cycle assessment of gasoline and diesel produced via fast pyrolysis and hydroprocessing. Technical Report TP-6A20-49341, National Renewable Energy Laboratory (NREL).

Huber, G. W., Corma, A., 2007. Synergies between bio-and oil refineries for the production of fuels from biomass. Angewandte Chemie International 46, 7184-7201.

IPCC, 2007. IPCC 4th Assessment Report: Working Group I Report “The Physical Science Basis”. Tech. rep., Intergovernmental Panel on Climate Change.

Karhu, K., Mattila, T., Bergstrom, I., Regina, K., 2011. Biochar addition to agricultural soil increased $\mathrm{ch}_{4}$ uptake and water holding capacity: Results from a short-term pilot field study. Agriculture, Ecosystems and Environment 140, 309-313.

Keeney, R., Hertel, T. W., 2009. The indirect land use impacts of us biofuel policies: the importance of acreage, yield, and bilateral trade responses. American Journal of Agricultural Economics 91, 895-909.

Kim, S., Dale, B. E., 2005. Life cycle assessment of various cropping systems utilized for producing biofuels: bioethanol and biodiesel. Biomass and Bioenergy 29, 426-439.

Kim, S., Dale, B. E., Jenkins, R., 2009. Life cycle assessment of corn grain and corn stover in the united states. The International Journal of Life Cycle Assessment 14, 160-174.

Kimetu, J. M., Lehmann, J., Ngoze, S. O., Mugendi, D. N., Kinyangi, J. M., Riha, S., Verchot, L., Recha, J. W., Pell, A. N., 2008. Reversibility of soil productivity decline with organic matter of differing quality along a degradation gradient. Ecosystems 11, 726-639.

Laird, D. A., amd James E. Amonette, R. C. B., Lehmann, J., 2009. Review of the pyrolysis platform for coproducing bio-oil and biochar. Biofuels, Bioproducts and Biorefining 3, 547-562.

Laird, D. A., Fleminga, P., Davis, D. D., Horton, R., Wang, B., Karlen, D. L., 2010. Impact of biochar amendments on the quality of a typical midwestern agricultural soil. Geoderma 158, 443-449.

Lehman, J., 2007. A handful of carbon. Nature 447, 143-144.

Lehmann, J., Czimczik, C., Laird, D. A., Sohi, S., 2009. Biochar for Environmental Management: Science and Technology. Routledge, Ch. Stability of biochar in soil, pp. 183-205.

Liang, B., Lehmann, J., Solomon, D., Kinyangi, J., Grossman, J., O’Neill, B., Skjemstad, J. O., Thies, J., Luizao, F. J., Petersen, J., Neves, E. G., 2006. Black carbon increases cation exchange capacity in soils. Soil Science Society of America Journal 70, 1719-1730.

Luo, L., van der Voet, E., Huppes, G., de Haes, H. A. U., 2009. Allocation issues in lca methodology: a case study of corn stover-based fuel ethanol. The International Journal of Life Cycle Assessment 14, 529-539.

Major, J., Rondon, M., Molina, D., Riha, S. J., Lehmann, J., 2010. Maize yield and nutrition during 4 years after 
biochar application to a colombian savanna oxisol. Plant and Soil 333, 117-128.

Mani, S., Tabil, L. G., Sokhansanj, S., 2004. Grinding performance and physical properties of wheat and barley straws, corn stover and switchgrass. Biomass and Bioenergy 27, 339-352.

Marris, E., 2006. Putting the carbon back: Black is the new green. Nature 442, 624-626.

Mathews, J. A., 2008. Carbon-negative biofuels. Energy Policy 36, 940-945.

McCarl, B. A., Peacocke, C., Chrisman, R., Kung, C.-C., Sands, R. D., 2009. Biochar for Environmental Management: Science and Technology. Routledge, Ch. Economics of biochar production, utilization and greenhouse gas offsets, pp. 341-357.

Melillo, J. M., Reilly, J. M., Kicklighter, D. W., Gurgel, A. C., Cronin, T. W., Paltsev, S., Felzer, B. S., Wang, X., Sokolov, A. P., Schlosser, C. A., 2009. Indirect emissions from biofuels: How important? Science 326 (5958), 1397-1399.

Mullen, C. A., Boateng, A. A., Goldberg, N. M., Lima, I. M., Laird, D. A., Hicks, K. B., 2010. Bio-oil and bio-char production from corn cobs and stover by fast pyrolysis. Biomass and Bioenergy 34, 67-74.

Novak, J. M., Busscher, W. J., Watts, D. W., Laird, D. A., Ahmedna, M. A., Niandou, M. A. S., 2010. Short-term CO 2 mineralization after additions of biochar and switchgrass to a Typic Kandiudult. Geoderma 154 (281-288).

Perlack, R. D., Stokes, B. J., 2011. U.S. Billion-Ton Update: Biomass Supply for a Bioenergy and Bioproducts Industry. ORNL/TM-2011/224. Oak Ridge National Laboratory, Oak Ridge, TN, U.S. Department of Energy.

Renner, R., 2007. Rethinking biochar. Environmental Science and Technology 41, 5932-5933.

Roberts, K. G., Gloy, B. A., Joseph, S., Scott, N. R., Lehmann, J., 2010. Life cycle assessment of biochar systems: estimating the energetic, economic, and climate change potential. Environmental Science and Technology 44, 827833.

Rogovska, N., Fleming, P., Laird, D. A., Cruse, R., Parkin, T., Meek, D., 2011. Impact of biochar on manure carbon stabilization and greenhouse gas emissions. Soil Science Society of America Journal 75, 871-879.

Rudel, T. K., Schneider, L., Uriarte, M., II, B. L. T., DeFries, R., Lawrence, D., Geoghegan, J., Hecht, S., Ickowitz, A., Lambin, E. F., Birkenholtz, T., Baptista, S., Grau, R., 2009. Agricultural intensification and changes in cultivated areas, 19702005. Proceedings of the National Academy of Sciences of the United States of America 106 (49), 2067520680.

Scheer, C., Grace, P. R., Rowlings, D. K., Kimber, S., Zwieten, L. V., 2011. Effect of biochar amendment on the soil-atmosphere exchange of greenhouse gases from an intensive subtropical pasture in northern new south wales, australia. Plant and Soil 345, 47-58.

Searchinger, T., Heimlich, R., Houghton, R. A., Dong, F., Elobeid, A., Fabiosa, J., Tokgoz, S., Hayes, D. J., Yu, T.H., 2008. Use of u.s. croplands for biofuels increases greenhouse gases through emissions from land-use change. Science 319 (5867), 1238-1240.

Sheehan, J., Aden, A., Paustian, K., Killian, K., Brenner, J., Walsh, M., Nelson, R., 2003. Energy and environmental aspects of using corn stover for fuel ethanol. Journal of Industrial Ecology 7 (117-146).

Singh, B. P., Hatton, B. J., Singh, B., Cowie, A. L., Kathuria, A., 2010. Influence of biochars on nitrous oxide emission and nitrogen leaching from two contrasting soils. Journal of Environmental Quality 39, 1224-1235.

Spokas, K., Cantrell, K., Novak, J., Archer, D., Ippolito, J., Collins, H., Boateng, A., Lima, I., Lamb, M., McAloon, A., Lentz, R., Nichols, K., 2010. Biochar: A synthesis of its agronomic impact beyond carbon sequestration. Journal of Environmental Quality 41, 973-989.

Wilhelm, W. W., Johnson, J. M. F., Karlen, D. L., Lightle, D. T., 2007. Corn stover to sustain soil organic carbon further constrains biomass supply. Agronomy Journal 99, 1665-1667.

Wright, M. M., Daugaard, D. E., Satrio, J. A., Brown, R. C., 2010. Techno-economic analysis of biomass fast pyrolysis to transportation fuels. Fuel 89, S2-S10.

Yanai, Y., Toyota, K., Okazaki, M., 2007. Effects of charcoal addition on $\mathrm{n}_{2} \mathrm{O}$ emissions from soil resulting from rewetting air-dried soil in short-term laboratory experiments. Soil Science and Plant Nutrition 53, 181-188.

Zimmerman, A. R., Gao, B., Ahn, M.-Y., 2011. Positive and negative carbon mineralization priming effects among a variety of biochar-amended soils. Soil Biology and Biochemistry 43, 1169-1179. 


\begin{tabular}{lr}
\hline Category & Emissions $\left(\mathrm{g} \mathrm{MJ}^{-1}\right)$ \\
\hline International Land-Use Change & 76.1 \\
Fuel and Feedstock Transport & 4.4 \\
Domestic Farm Inputs and Fertilizer N2O & 5.4 \\
Domestic Soil Carbon & 0.1 \\
Domestic Livestock & -3.4 \\
Domestic Rice Methane & -1.6 \\
Intl Farm Inputs and Fertilizer N2O & 9.3 \\
International Livestock & -1.3 \\
International Rice Methane & -1.2 \\
Tailpipe & 0.8 \\
Fuel Production Emissions & 30.7 \\
\hline Total & 119.3 \\
\hline
\end{tabular}

Table 1: EPA Corn Grain Ethanol Greenhouse Gas Emissions (2012) 


\begin{tabular}{|c|c|c|}
\hline Parameter & Value & Source \\
\hline Global warming potential of $\mathrm{CH}_{4}$ & 25 & IPCC (2007) \\
\hline Global warming potential of $\mathrm{N}_{2} \mathrm{O}$ & 298 & IPCC (2007) \\
\hline Biochar yield $(\%) *$ & 17 & Mullen et al. (2010) \\
\hline Stover removal without biochar $(\%) *$ & 40 & Assumed value \\
\hline Stover removal with biochar $(\%) *$ & 70 & Assumed value \\
\hline Bio-oil yield $(\%) *$ & 61.7 & Mullen et al. (2010) \\
\hline Biochar used in pyrolysis $(\%) *$ & 33.3 & Wright et al. (2010) \\
\hline Bio-oil to bio-gasoline conversion $(\%) *$ & 42 & Wright et al. (2010) \\
\hline Bio-oil for hydrogen production $(\%) *$ & 38 & Wright et al. (2010) \\
\hline Biomass at pyrolysis facility $\left({\left.\mathrm{t} \mathrm{yr}^{-1}\right)}^{-1}\right.$ & 70,000 & McCarl et al. (2009); Wright et al. (2010) \\
\hline Carbon content of biochar $(\%)$ & 37.8 & Brewer et al. (2009) \\
\hline Percentage of carbon in feedstock & 45 & McCarl et al. (2009) \\
\hline Carbon taken from sequestered soil $(\%)$ & 2 & McCarl et al. (2009) \\
\hline Dry Mill Plants (\%) & 63 & \\
\hline Moisture content $(\%)$ & 15 & \\
\hline \multicolumn{3}{|c|}{ Emissions in $\mathrm{kg} \mathrm{CO}_{2} \mathrm{e}^{-1}$ stover } \\
\hline Corn stover collection & 19.936 & GREET V1.8c.0 \\
\hline Nutrient replacement & 20.572 & GREET V1.8c.0 \\
\hline Stover transportation & 1.704 & GREET V1.8c.0 \\
\hline Gasoline displacement & -600.049 & \\
\hline Pyrolysis operations & 17.237 & GREET V1.8c.0 \\
\hline Bio-oil transportation & 65.302 & GREET V1.8c.0 \\
\hline Upgrading bio-oil into bio-gasoline & 73.080 & GREET V1.8c.0 \\
\hline Bio-gasoline distribution & 3.077 & GREET V1.8c.0 \\
\hline Fertilizer displacement & -12.375 & Roberts et al. (2010) \\
\hline Biochar application & 10.477 & \\
\hline Biochar sequestration gain & -146.084 & Roberts et al. (2010) \\
\hline Biochar sequestration loss & 33.000 & McCarl et al. (2009) \\
\hline
\end{tabular}

Table 2: Key assumptions and references for the life cycle calculations. The emissions in $\mathrm{kg} \mathrm{CO}_{2} \mathrm{t}^{-1}$ wet stover have several components that are outlined in detail in the supporting information. The parameters marked with a "*” are subject to a sensitivity analysis. 


\begin{tabular}{|c|c|c|c|c|c|c|}
\hline \multirow[b]{2}{*}{ Year } & \multicolumn{4}{|c|}{ Emissions in $\mathrm{t} \mathrm{CO}_{2} \mathrm{ha}^{-1}$} & \multirow[b]{2}{*}{$\begin{array}{l}\text { Energy } \\
\text { Yield } \\
(\mathrm{MJ} \\
\left.\mathrm{ha}^{-1}\right)\end{array}$} & \multirow[b]{2}{*}{$\begin{array}{l}\text { Total } \\
(\mathrm{g} \\
\left.\mathrm{MJ}^{-1}\right)\end{array}$} \\
\hline & $\begin{array}{l}\text { Grain } \\
\text { to } \\
\text { Ethanol }\end{array}$ & Pyroly & $\begin{array}{l}\text { s ILUC } \\
\text { Credit }\end{array}$ & Total & & \\
\hline 2011 & 10.79 & -2.05 & 0.00 & 8.74 & 0.09 & 96.60 \\
\hline 2012 & 10.94 & -2.11 & 0.00 & 8.83 & 0.09 & 96.30 \\
\hline 2013 & 11.09 & -2.17 & 0.00 & 8.91 & 0.09 & 95.90 \\
\hline 2014 & 11.23 & -2.24 & 0.00 & 8.99 & 0.09 & 95.50 \\
\hline 2015 & 11.38 & -2.30 & 0.00 & 9.07 & 0.10 & 95.10 \\
\hline 2016 & 11.52 & -2.37 & 0.00 & 9.15 & 0.10 & 94.70 \\
\hline 2017 & 11.67 & -2.44 & 0.00 & 9.22 & 0.10 & 94.30 \\
\hline 2018 & 11.82 & -2.52 & 0.00 & 9.29 & 0.10 & 93.80 \\
\hline 2019 & 11.96 & -2.59 & 0.00 & 9.36 & 0.10 & 93.40 \\
\hline 2020 & 12.11 & -2.67 & 0.00 & 9.43 & 0.10 & 92.90 \\
\hline 2021 & 12.25 & -2.75 & 0.00 & 9.50 & 0.10 & 92.50 \\
\hline 2022 & 12.40 & -2.83 & 0.00 & 9.56 & 0.10 & 92.00 \\
\hline 2023 & 12.54 & -2.92 & 0.00 & 9.62 & 0.11 & 91.50 \\
\hline 2024 & 12.69 & -3.01 & 0.00 & 9.68 & 0.11 & 91.00 \\
\hline 2025 & 12.84 & -3.10 & 0.00 & 9.73 & 0.11 & 90.50 \\
\hline 2026 & 12.98 & -3.19 & 0.00 & 9.78 & 0.11 & 89.90 \\
\hline 2027 & 13.13 & -3.29 & 0.00 & 9.83 & 0.11 & 89.40 \\
\hline 2028 & 13.27 & -3.39 & 0.00 & 9.88 & 0.11 & 88.80 \\
\hline 2029 & 13.42 & -3.49 & 0.00 & 9.92 & 0.11 & 88.20 \\
\hline 2030 & 13.57 & -3.60 & 0.00 & 9.96 & 0.11 & 87.60 \\
\hline 2031 & 13.71 & -3.71 & 0.00 & 9.99 & 0.11 & 87.00 \\
\hline 2032 & 13.86 & -3.83 & 0.00 & 10.03 & 0.12 & 86.30 \\
\hline 2033 & 14.00 & -3.94 & 0.00 & 10.05 & 0.12 & 85.70 \\
\hline 2034 & 14.15 & -4.07 & 0.00 & 10.08 & 0.12 & 85.00 \\
\hline 2035 & 14.30 & -4.19 & 0.00 & 10.10 & 0.12 & 84.30 \\
\hline 2036 & 14.44 & -4.32 & 0.00 & 10.11 & 0.12 & 83.60 \\
\hline 2037 & 14.59 & -4.46 & 0.00 & 10.12 & 0.12 & 82.80 \\
\hline 2038 & 14.73 & -4.60 & 0.00 & 10.13 & 0.12 & 82.00 \\
\hline 2039 & 14.88 & -4.74 & 0.00 & 10.13 & 0.12 & 81.30 \\
\hline 2040 & 15.02 & -4.89 & 0.00 & 10.13 & 0.13 & 80.40 \\
\hline
\end{tabular}

Table 3: Baseline "No Yield Improvement": Emissions components of the dynamic calculation with no biocharinduced yield improvement 


\begin{tabular}{|c|c|c|c|c|c|c|}
\hline \multirow[b]{2}{*}{ Year } & \multicolumn{4}{|c|}{ Emissions in $\mathrm{t} \mathrm{CO}_{2} \mathrm{ha}^{-1}$} & \multirow[b]{2}{*}{$\begin{array}{l}\text { Energy } \\
\text { Yield } \\
(\mathrm{MJ} \\
\left.\mathrm{ha}^{-1}\right)\end{array}$} & \multirow[b]{2}{*}{$\begin{array}{l}\text { Total } \\
(\mathrm{g} \\
\left.\mathrm{MJ}^{-1}\right)\end{array}$} \\
\hline & $\begin{array}{l}\text { Grain } \\
\text { to } \\
\text { Ethanol }\end{array}$ & Pyrolys & $\begin{array}{l}\text { s ILUC } \\
\text { Credit }\end{array}$ & Total & & \\
\hline 2011 & 10.79 & -2.05 & 0.00 & 8.74 & 0.09 & 96.60 \\
\hline 2012 & 10.95 & -2.11 & -0.01 & 8.83 & 0.09 & 96.31 \\
\hline 2013 & 11.11 & -2.18 & -0.03 & 8.90 & 0.09 & 95.80 \\
\hline 2014 & 11.27 & -2.25 & -0.06 & 8.96 & 0.09 & 95.18 \\
\hline 2015 & 11.44 & -2.32 & -0.11 & 9.01 & 0.10 & 94.43 \\
\hline 2016 & 11.60 & -2.39 & -0.17 & 9.04 & 0.10 & 93.55 \\
\hline 2017 & 11.76 & -2.46 & -0.24 & 9.05 & 0.10 & 92.53 \\
\hline 2018 & 11.93 & -2.54 & -0.34 & 9.04 & 0.10 & 91.26 \\
\hline 2019 & 12.09 & -2.62 & -0.45 & 9.02 & 0.10 & 89.93 \\
\hline 2020 & 12.26 & -2.71 & -0.58 & 8.97 & 0.10 & 88.33 \\
\hline 2021 & 12.42 & -2.79 & -0.73 & 8.90 & 0.10 & 86.66 \\
\hline 2022 & 12.59 & -2.88 & -0.90 & 8.80 & 0.10 & 84.70 \\
\hline 2023 & 12.76 & -2.98 & -1.10 & 8.68 & 0.11 & 82.54 \\
\hline 2024 & 12.93 & -3.07 & -1.33 & 8.53 & 0.11 & 80.18 \\
\hline 2025 & 13.11 & -3.17 & -1.58 & 8.34 & 0.11 & 77.59 \\
\hline 2026 & 13.28 & -3.27 & -1.87 & 8.13 & 0.11 & 74.69 \\
\hline 2027 & 13.45 & -3.38 & -2.18 & 7.88 & 0.11 & 71.62 \\
\hline 2028 & 13.63 & -3.49 & -2.54 & 7.59 & 0.11 & 68.21 \\
\hline 2029 & 13.81 & -3.61 & -2.93 & 7.26 & 0.11 & 64.52 \\
\hline 2030 & 13.98 & -3.73 & -3.36 & 6.88 & 0.11 & 60.55 \\
\hline 2031 & 14.17 & -3.85 & -3.83 & 6.46 & 0.11 & 56.26 \\
\hline 2032 & 14.35 & -3.98 & -4.36 & 5.99 & 0.12 & 51.59 \\
\hline 2033 & 14.53 & -4.12 & -4.93 & 5.47 & 0.12 & 46.64 \\
\hline 2034 & 14.72 & -4.26 & -5.55 & 4.89 & 0.12 & 41.26 \\
\hline 2035 & 14.90 & -4.40 & -6.23 & 4.25 & 0.12 & 35.50 \\
\hline 2036 & 15.09 & -4.56 & -6.97 & 3.55 & 0.12 & 29.33 \\
\hline 2037 & 15.28 & -4.71 & -7.78 & 2.78 & 0.12 & 22.70 \\
\hline 2038 & 15.48 & -4.88 & -8.65 & 1.93 & 0.12 & 15.63 \\
\hline 2039 & 15.67 & -5.05 & -9.60 & 1.01 & 0.12 & 8.08 \\
\hline 2040 & 15.87 & -5.23 & -10.62 & 0.00 & 0.13 & 0.00 \\
\hline
\end{tabular}

Table 4: Scenario "Break-Even Yield Improvement": Emissions components of the dynamic calculation with biocharinduced yield improvement of $5.89 \%$ 